for the student, however much time and labour for the teacher are saved thereby. The frog's skull, for example, has been drawn with every bone outlined, and all the student need do is insert the names and send in his sheet to be marked. The author aims at making the student "rely on his own judgment". Surely it is equally important to stimulate and train his powers of observation.

In the first insect type the name of the insect has been omitted, and the reviewer's copy has a duplicate page in this section. The descriptions are clearly expressed, and since scientific terms and new words are printed in italics, the student can look these up in the "Text-book of Zoology" previously published by the author.

\section{Nature Parade}

By Frank W. Lane. Pp. $316+53$ plates. (London: Jarrolds, Ltd., 1939.) 15s. net.

$\mathrm{B}^{\mathrm{Y}}$ far the majority of books which set out to describe events and happenings in nature are limited in that they are personal records of one or two observers only. The value of this book lies in the fact that the author has made a synthesis of innumerable records from various observers. The more general sections deal with subjects like animal food, toilet, sleep, leadership, strength, war and doctoring, while a considerable portion of the book is given over to a useful and original résumé of speed and locomotion in the animal kingdom. In a shorter section, which falls below the standard of the rest of the book, there is a rather verbose description of rare and mystical animals. "Nature Parade" rightly justifies its author's claim to be "a nature book with a difference" and contains much interesting information. It suffers by its too 'popular' and anthropomorphic approach and the absence of references to original documents. Some remarkable photographs by leading nature photographers do much to enhance the usefulness of the book.

T. H. H.

\section{A Contribution to the Biology of North American Vespine Wasps \\ By Prof. Carl D. Duncan. (Stanford University Publications, University Series: Biological Sciences, Vol. 8, No. 1.) Pp. $272+54$ plates. (Stanford Univer- sity, Calif. : Stanford University Press; London : Oxford University Press, 1939.) 15s. net.}

\footnotetext{
7 HIS memoir deals with North American papermaking wasps of the subfamily Vespinæ. It is divided into four sections : an introduction, a morphological section, a systematic section and a biological section. The morphology is concerned with the skeletal and muscular systems of Vespula pennsylvanica. The systematic part is concerned with genera and not species, while as regards biology numerous observations are given on habits, behaviour, nest-building and life-history. An extensive bibliography is appended, but the literature is not exhaustively reviewed, since the work is in no sense claimed to be a monograph.
}

\section{Chemistry}

Laboratory Exercises in Inorganic Chemistry By Prof. James F. Norris and Prof. Kenneth I. Mark. (International Chemical Series.) Second edition. Pp. xiii +574. (New York and London : McGraw-Hill Book Co., Inc., 1939.) $12 s$.

WVITH the publication of a new edition of "Inorganic Chemistry for Colleges", Profs. Norris and Mark have now revised "Laboratory Exercises in Inorganic Chemistry" to make it complementary to the theoretical treatise. Additional experiments have been introduced to illustrate the chemistry of colloids, $p \mathrm{H}$, and buffer solutions; otherwise the general plan of the book remains as before.

It is often said that experience is the best teacher, and the authors have fully supported this view in presenting a book which gives thorough training to students in all branches of practical inorganic chemistry. Very wisely, special emphasis is laid on the acquisition of fundamental bench technique as an early step in the student's training. This is followed by a systematic course covering the preparation and well-known reactions of many simple inorganic chemicals.

Each exercise consists of three parts : discussion, practical directions and questions. The last part is formulated in such a manner as to show that both the chemistry and the technique of the exercises have been mastered. An unusual feature of the book is the provision of blank pages for the students' notes. This system, which renders the book ultimately a combined text-book and note-book, should be of great value to the instructor.

The book can be heartily recommended to students entering on a chemical course. A careful study of the theory contained in the text and a mastery of the laboratory technique presented will prove a sound basis should the student desire to embark on more advanced chemical courses.

The Chemistry of Milk

By Dr. W. L. Dẫies. (Monographs on Applied Chemistry, Vol. 10.) Second edition. Pp. xiv +534 . (London : Chapman and Hall, Ltd., 1939.) 25s. net.

TN reviewing the first edition of this book in 1 Nature, 138, 625 (1936), attention was directed to the rather large number of errors and inaccuracies in what should have been an indispensable and infallible weapon in the hands of the dairy technologist. So far as can be discovered, a few of these errors have been corrected in the new edition, but many remain. In addition to those cited in the NATURE review-and in others-may be mentioned a misquotation of Baumann and Steenbock (p. 490, last line but four), who found a 200 per cent variation in thə vitamin A content of butter - not a 100 per cent variation, as stated by Dr. Davies.

The book remains the only work of its kind published in Great Britain. Every dairy chemist in the Empire probably possesses or has access to a copy. It is a national and imperial duty to secure that the 